\title{
First records of Uromyces glycyrrhizae (Pucciniales) in Ukraine
}

\author{
Yuri Ya. TYKHONENKO, Liudmyla P. VAKARENKO \\ M.G. Kholodny Institute of Botany, National Academy of Sciences of Ukraine \\ 2 Tereshchenkivska Str., Kyiv 01004, Ukraine \\ yu.ya.tykhonenko@gmail.com \\ larix04@ukr.net
}

Tykhonenko Yu.Ya., Vakarenko L.P. First records of Uromyces glycyrrhizae (Pucciniales) in Ukraine. Ukr. Bot. J., 2018, 75(2): 187-190.

Abstract. Epiphytotic development of a new for Ukraine rust fungus Uromyces glycyrrhizae was recorded in May and September 2017 on the eastern shore of Kuyalnik Estuary (Odesa Region, Ukraine) on Glycyrrhiza glabra, a species listed in the Red Data Book of Ukraine. Hitherto, the fungus was reported for Europe, northern Africa, Asia and North America. The reason why U. glycyrrhizae was recorded in Ukraine only recently remains unclear, but taking into account that this species in Europe is confined to its warmer part, climate change might be argued as a cause of this. The article is illustrated by original micrographs.

Keywords: rust fungi, Glycyrrhiza glabra, distribution, morphology

\section{Introduction}

The genus Glycyrrhiza L. comprises about 20 species distributed mainly in temperate Eurasia and in North Africa. Only few species are known from outside Eurasia: G. acanthocarpa (Lindl.) J.M. Black is native of Australia, G. astragalina Hook. \& Arn. - of South America, and G. lepidota Pursh - of North America (The Plant List, 2013). In Ukraine three species of this genus occur. Glycyrrhiza glabra L. distributed in coastal areas of the Black and Azov seas is listed in the Red Data Book of Ukraine (Fedoronchuk, 2009). Uromyces glycyrrhizae (Rabenh.) Magnus parasitizing several species of Glycyrrhiza in Eurasia and North America hitherto was unknown in Ukraine.

Here we report the first for Ukraine records of this fungus and provide some data on its morphology, occurrence, and life cycle.

\section{Materials and methods}

Systemically infected plants of G. glabra were collected in Odesa Region, Ukraine. The specimens were studied under a dissecting microscope, labelled and dried for further treatment. Aecio- and teliospores mounted in water or lactic acid were investigated by light microscopy. Photomicrographs were taken under Primo Star microscope, Canon A300 digital camera and AxioVision 4.7 software, used as well for measurements (C) Yu.Ya. TYKHONENKO, L.P. VAKARENKO, 2018 of microstructures. For scanning electron microscopy, samples were covered with an ultrathin coating of gold by ion beam sputtering unit JFC-1100. Images were obtained by a scanning electron microscope JEOL JSM-6060 LA.

Analysis of general distribution is based on the data from literature (González Fragoso, 1925; Arthur, 1934; Tranzschel, 1939; Savulescu, 1953; Guyot, 1957; Casulli, Ippolito, 1995; Denchev, 1995; Braun, 1999; Zhuang, 2005; Savchenko et al., 2014) and databases available through the Internet, including GBIF Portal (GBIF Secretariat, 2018), USDA Fungal Database (Farr, Rossman, 2018), etc.

The specimens are deposited in the Mycological Herbarium of the M.G. Kholodny Institute of Botany, National Academy of Sciences of Ukraine (KW-M).

\section{Results and discussion}

Epiphytotic development of a new for Ukraine fungus, Uromyces glycyrrhizae was recorded in May and September 2017 on Glycyrrhiza glabra, a species listed in the Red Data Book of Ukraine. Infected plants were collected in a plant community dominated by Bromus inermis Leyss. (cover percentage is 70\%), with G. glabra as a codominant (cover percentage is $30-50 \%$ ). A diagnosis and original illustrations of the species, data on its distribution, morphology and phenology are provided below. 


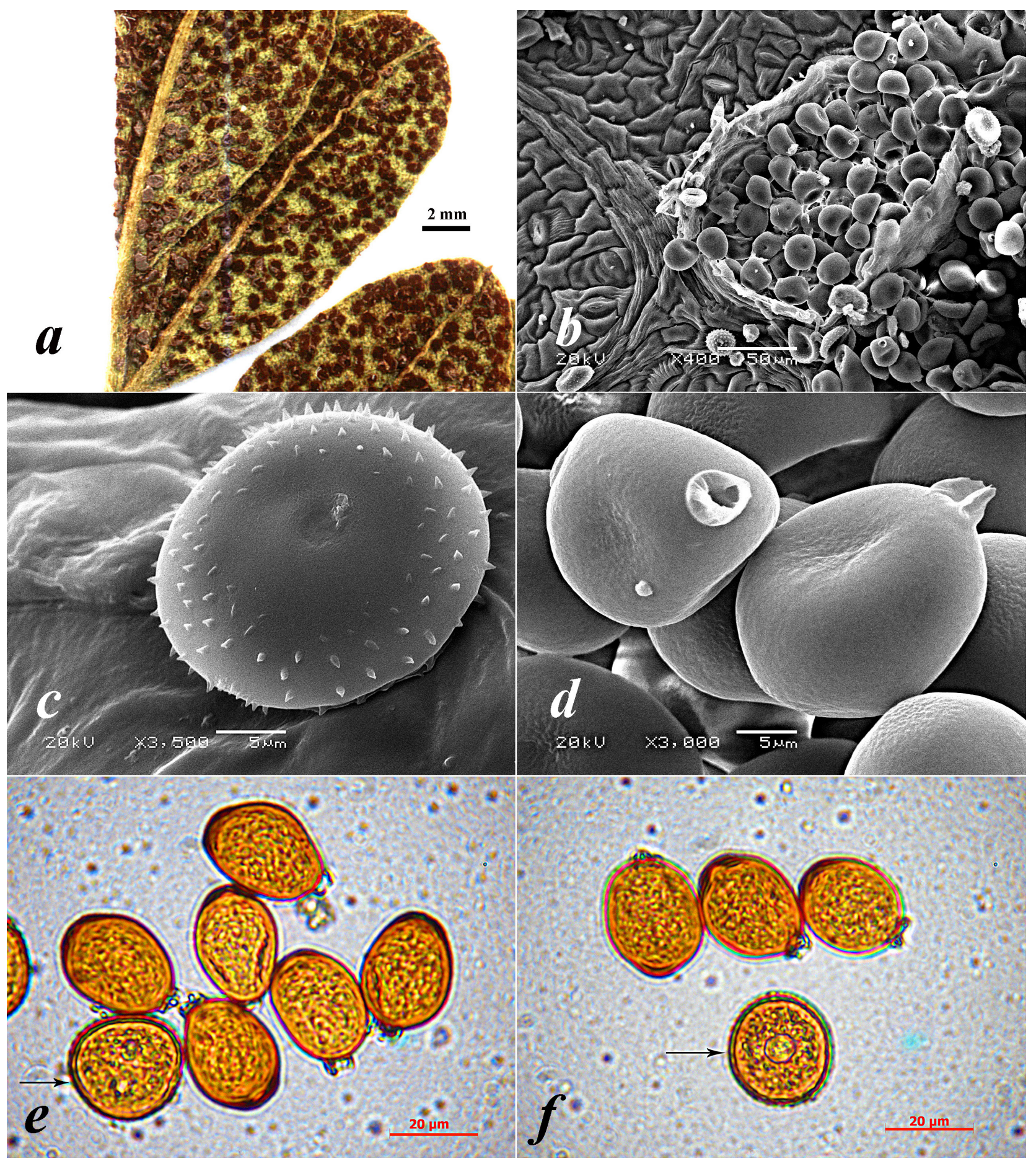

Uromyces glycyrrhizae: $a$ - habit of aecia on Glycyrrhiza glabra; $b$ - scanning electron microscopy of telium; $c$ - scanning electron microscopy of aeciospore; $d$ - scanning electron microscopy of teliospores; $e, f$ - light microscopy of aeciospores (indicated by arrows) and teliospores 
Uromyces glycyrrhizae (Rabenh.) Magnus, Ber. dt. bot. Ges. 8: 383. 1890. - Puccinia glycyrrhizae Rabenh., Bot. Ztg. 8: 438. 1850. - Dicaeoma glycyrhizae (Rabenh.) Kuntze, Revis. gen. pl. (Leipzig) 3(2): 469. 1898. - Klebahnia glycyrrhizae (Rabenh.) Arthur, Résult. Sci. Congr. Bot. Wien 1905: 345. 1906.

Spermogonia mainly hypophyllous, systemic. Aecia mostly hypophyllous, uredinoid, systemic, dark cinnamon-brown (Figure, a). Aeciospores globoid, 23-32 × 24-32 $\mu \mathrm{m}$, flattened laterally, wall chestnutbrown, 1-2 $\mu \mathrm{m}$ thick, echinulate, with two equatorial pores, spore surface around pores free of spines (Figure, $c, e, f)$. Uredinia wanting, or if present indistinguishable from the aecia. Urediniospores in localized telia, resembling aeciospores. Telia chiefly hypophyllous, either systemic or developed from localized mycelium, dark chestnut-brown (Figure, $b$ ). Teliospores ellipsoid, 15-22 $\times 23-32 \mu \mathrm{m}$, wall chestnut-brown, uniformly $1.5-2.5 \mu \mathrm{m}$ thick, with a hyaline umbo over the pore, smooth, pedicel colourless, short, fragile (Figure, $d, e, f$ ).

Distribution in Ukraine. On Glycyrrhiza glabra: Odesa Region, on the eastern shore of Kuyalnik Estuary, $46^{\circ} 41^{\prime} 08^{\prime \prime}$ N, $30^{\circ} 42^{\prime} 55^{\prime \prime}$ E, 31.05.2017, L.P. Vakarenko (KW-M70925), 21.09.2017, L.P. Vakarenko (KWM70926).

General distribution. Europe: Bulgaria, Czech Republic, Greece, Italy, Portugal, Romania, Russia, Spain, Ukraine (current report). Northern Africa: Algeria, Libya. Asia: Armenia, Azerbaijan, China, Georgia, Iran, Iraq, Israel, Japan, Kazakhstan, Kyrgyzstan, Mongolia, Pakistan, Russia, Tajikistan, Turkey, Turkmenistan, Uzbekistan. North America: central and western states of the USA.

In Europe only two other species of Uromyces cause systemic infection of legumes of the tribe Galegeae, and they clearly differ from U. glycyrrhizae. Uromyces lapponicus Lagerh. has aecidioid aecia and verrucose teliospores whereas $U$. phacae-frigidae (Wahlenb.) Har. produces only telia with verrucose teliospores. Both species occur in arctic regions and mountains of Eurasia and North America, so in terms of biogeography they are also quite different from U. glycyrrhizae.

A special study on phenology of $U$. glycyrrhizae (Luo et al., 1992) revealed that urediospores and basidiospores formed from teliospores infect the basal buds of licorice plants before winter and remain dormant there. The following spring, the infected buds produce stems with systemic infection.
Aecial and telial stages of $U$. glycyrrhizae last for the extended period. Our specimen collected in May bears aecia, whereas a specimen collected in September shows telia with only a small admixture of aeciospores.

The reason why $U$. glycyrrhizae was recorded in Ukraine only recently, remains unclear. Taking into account that this species in Europe is confined to its warmer part, climate change might be argued as a cause of this; however, our records are not the northernmost ones in Europe since the species was noted as far north as Saratov, Russia $\left(51^{\circ} \mathrm{N}\right)$ (Tranzschel, 1939). The possibility that $U$. glycyrrhizae was merely overlooked is also rather unlikely. Natural populations of G. glabra in Ukraine were regularly surveyed during the last 20 years and, due to systemic character of the disease, plants infected by $U$. glycyrrhizae are quite different from the healthy ones and clearly visible; moreover, such symptoms of the parasite last for almost whole vegetation season.

\section{Acknowledgements}

We are grateful to Prof. D.V. Dubyna and Dr. T.P. Dziuba for their support during the field work and to N.S. Novichenko, a staff member of the M.G. Kholodny Institute of Botany NASU, for his technical assistance in scanning electron microscopy.

\section{REFERENCES}

Arthur J.C. Manual of the rusts in United States and Canada. Lafayette, Indiana: Purdue Res. Found., 1934, 438 pp.

Braun U. An annotated list of Mongolian phytoparasitic micromycetes. Schlechtendalia, 1999, 3: 1-32.

Casulli F., Ippolito A. Osservazioni sulla ruggine della liquirizia (Uromyces glycyrrhizae (Rab.) Magn.) in Italia meridionale. Informatore Fitopatologico, 1995, 45(11): 27-30.

Denchev C.M. Bulgarian Uredinales. Mycotaxon, 1995, 55: 405-465.

Farr D.F., Rossman A.Y. Fungal Databases, U.S. National Fungus Collections, ARS, USDA, available at: https:// nt.ars-grin.gov/fungaldatabases/ (accessed 27 February, 2018).

Fedoronchuk M.M. Glycyrrhiza glabra. In: Chervona knyha Ukrainy. Roslynnyi svit (Red Data Book of Ukraine. Plant Kingdom). Ed. Ya.P. Didukh. Kyiv: Globalconsulting, 2009, p. 466. [Федорончук М.M. Glycyrrhiza glabra. В кн.: Червона книга України. Рослинний світ. Ред. Я.П. Дідух. Київ: Глобалконсалтинг, 2009, с. 466].

GBIF Secretariat: GBIF Backbone Taxonomy. doi. org/10.15468/39omei, available at: https://www.gbif. org/species/3380345 (accessed 2018-03-01).

González Fragoso R. Uredales (Royas de los Vegetales). Tomo 2. Género Uromyces etc.: Uredales imperfectos. Madrid: Museo Nacional de Ciencias Naturales, 1925, 424 pp. 
Guyot A.L. Les Rouilles des Légumineuses Fourragères et Spontanées. Paris: Editions Paul Lechevalier, 1957, $647 \mathrm{pp}$.

Luo Y.W., Xue G.S., Chen X.W. Studies on the spore stages, life cycle and control of liquorice rust. Acta Phytophylacica Sinica, 1992, 19(2): 127-132.

Savchenko K.G., Heluta V.P., Wasser S.P., Nevo E. Rust fungi (Pucciniales) of Israel. II. The genus Uromyces. Nova Hedwigia, 2014, 98(3-4): 393-407.

Savulescu T. Monografia uredinalelor din Republica Popularâ Românâ. Bucureşti: Editura Academiei Republicii Populare Române, 1953, vol. 2, 727 pp.

The Plant List (2013). Version 1.1. Published on the Internet; available at: http://www.theplantlist.org/ (accessed 01 March 2018).

Transhel [Tranzschel] V.G. Obzor rzhavchinnykh gribov SSSR. Moscow: Izd-vo AN SSSR, 1939, 426 pp. [Траншель В.Г. Обзор ржавчинных грибов СССР. М.: Изд-во АН СССР, 1939, 426 с.].

Zhuang J.-Y. Flora Fungorum Sinicorum. Uredinales (III). Beijing: Science Press, 2005, vol. 25, 183 pp.

Recommended for publication

Submitted 12.03.2018 by V.P. Hayova

Тихоненко Ю.Я., Вакаренко Л.П. Перші знахідки Uromyces glycyrrhizae (Pucciniales) в Україні. Укр. бот. журн., 2018, 75(2): 187-190.

Інститут ботаніки ім. М.Г. Холодного НАН України вул. Терещенківська, 2, Київ 01004, Україна

У травні та вересні 2017 р. на східному узбережжі Куяльницького лиману (Одеська обл., Україна) на Glycyrrhiza glabra - рослині, включений до Червоної книги України, було відмічено епіфітотійний розвиток нового для України іржастого гриба Uromyces glycyrrhizae. До нашої знахідки цей вид був відомий з Европи, північної Африки, Азії та Північної Америки. Причини того, чому U. glycyrrhizae був відмічений в Україні лише нешодавно, залишаються нез'ясованими, але, беручи до уваги, що в Європі цей вид поширений тільки в південних регіонах, це може бути обумовлено глобальними змінами клімату. Стаття ілюстрована оригінальними мікрофотографіями.

Ключові слова: іржасті гриби, Glycyrrhiza glabra, поширення, морфологія
Тихоненко Ю.Я., Вакаренко Л.П. Первые находки Uromyces glycyrrhizae (Pucciniales) в Украине. УКр. бот. журн., 2018, 75(2): 187-190.

Институт ботаники им. Н.Г. Холодного НАН Украины ул. Терещенковская, 2, Киев 01004, Украина

В мае и сентябре 2017 г. на восточном побережье Куяльницкого лимана (Одесская обл., Украина) на Glycyrrhiza glabra - растении, внесенном в Красную книгу Украины, было отмечено эпифитотийное развитие нового для Украины ржавчинного гриба Uromyces glycyrrhizae. До нашей находки этот вид был известен из Европы, северной Африки, Азии и Северной Америки. Причины того, почему U. glycyrrhizae был отмечен в Украине лишь недавно, остаются невыясненными, однако, принимая во внимание, что в Европе этот вид распространен только в южных регионах, это может быть обусловлено глобальными изменениями климата. Статья иллюстрирована оригинальными микрофотографиями.

Ключевые слова: ржавчинные грибы, Glycyrrhiza glabra, распространение, морфология 